\title{
Yhteiskunnan muutos ja yliopistoyksikön selviytymishaasteet
}

\author{
Veikko Teikari \\ “Jos henkilöstö koostuu, kuten työpsykologian \\ laitoksella, diplomi-insinööreistä, psykologeista, \\ aikuiskasvattajista ja ekonomeista, saadaan aikaan \\ foorumi, jossa eri tiedepohjalta ponnistavat ihmiset \\ voivat ratkoa riittävän isoja kehittämisongelmia \\ muuttuvassa työelämässä, missä ongelmat ovat \\ kietoutuneet toisiinsa“, sanoo Teknillisen \\ korkeakoulun professori Veikko Teikari.
}

\begin{abstract}
Kun maailman poliittiset blokkirajat murtuivat muutama vuosi sitten, alkoi uusi aikakausi, jonka ohjaus toteutuu uusilla pelisäännöillä. Vapaa kilpailu tunkeutuu entisten suljettujenkin talousalueiden kotimarkkinoille ja jopa julkishallintoon. Ilmiö etenee monikansallisten yhtiöiden johdolla. Niiden päätöksentekoon kansallisvaltiot yrittävät reagoida ja vaikuttaa säilyttääkseen teolliset työpaikkansa. Vain lisäarvoa tuottavat yritykset ja yhteisöt kasvattavat merkitystään ja valtaansa.
\end{abstract}

Niinpä yritysten ja yhteisöjen johdossa mietitään sitä, miten organisaation menestys kyetään turvaamaan yhä kovenevassa kilpailussa ja henkilökunta - määrältään usein vähentynyt - saadaan antamaan tehokkaasti ja innostuneesti oman panoksensa yhtiön menestymisen hyväksi.

Tämä kehitys merkitsee sitä, että olemme yhä kovemmin juoksevassa susilaumassa. Selviytymisvaihtoehtoja on kaksi: täytyy juosta ensimmäis- 
ten joukossa tai on lähdettävä sovinnolla erakoksi. Suomi on valinnut ensimmäisen vaihtoehdon ja nyt sen eteen on ryhdyttävä työskentelemään täysipainoisesti. Uskon, että suomalainen yhteiskunta ja työelämä pärjäävät tällaisessa susilaumassa ilmeisesti ihan hyvin, jos pyrimme jalostamaan nykyisen kasvavan osaamisemme ja hyvän kansallisen infrastruktuurimme huippuluokan tuotteiksi, toimintaprosesseiksi ja osaamiseksi. Tämä edellyttää, että löydetään sellaiset työvälineet ja voimavarat, joilla visiot muunnetaan luoviksi strategioiksi, toimenpiteiksi ja tuloksiksi.

$\mathrm{T}$ yöpaikan keinot selvitä "maailman susilaumassa“" puolestaan keskittyvät yhdessä tekemiseen, luottamuspääoman kasvattamiseen ja yhdessä oppimisen parantamiseen. On luotava prosessi, jossa kaikki voittavat eli yrityksen tuottavuus ja tulos ovat maailman huippuluokkaa ja henkilöstön hyvinvointi yhdessä vaikutusmahdollisuuksien kanssa paranee. Tällöin on varaa myös parempaan taloudelliseen palkitsemiseen tulospalkan avulla. Tällöin pystytään hoitamaan myös heikompiosaiset ja säilyttämään ydin pohjoismaisesta hyvinvointivaltiosta.

$\mathrm{T}$ ässä yhteiskunnan ja työelämän menestymisen turvaamisessa kääntyy huomio teknologisten ja automaatioon liittyvien investointien ohella yhä enemmän juuri yritysten ja työyhteisöjen henkilöstöjen kehittämiseen. Jokainen ymmärtää, että uusi aika vaatii yhteistyötä ja luottamusta, sillä susilaumassa ei selviä raadeltuna. Yritysjohto ei pysty yksin selviämään haasteista ilman pätevää henkilökuntaa. Toisaalta, jos yritys ei menesty, henkilöstöllä ei edes ole työpaikkoja. Ainoa vaihtoehto on menestyä yhdessä.

$\mathrm{G}$ lobaali maailmantalous, jota Ilkka Tuomikin Nokialta kuvailee, ainakin murrosvaiheessa johtaa sekä polarisoitumiseen että fragmentoitumiseen. Jos seutukunta onnistuu saamaan alueelleen kansainvälisen yrityksen tuotantolaitoksen tai muutamia tällaisia, niiden ympärille syntyy alihankintaan erikoistuvien pkt-yritysten verkosto. Nämä tarvitsevat pätevää henkilöstöä, joten yliopisto ja ammattikorkeakouluja tarvitaan. Seutukunnan palveluista ja muusta infrastruktuurista pidetään hyvää huolta, jotta ammattilaiset saadaan pysymään siellä ja jotta heitä voidaan rekrytoida myös tulevaisuudessa. Myös kunnat voivat hyvin riittävillä verotuloilla.

Yritykset tulevat rahoittamaan avainhenkilöstönsä jatko- ja täydennyskoulutuksen erilaisten yhteistyösopimusten avulla. Jos suomalainen yhteiskunta kieltää toiminnan esimerkiksi tasa-arvosyistä, kehittäminen ostetaan ulkomaisilta yliopistoilta ja kansainvälisiltä koulutusyksiköiltä. Tämä vaihtoehto vienee myös suunnittelutyöt kiihtyvällä vauhdilla ulkomaille jo vietyjen teollisten työpaikkojen lisäksi. Suomalainen yhteiskunta joutuu arvokeskusteluun siitä, mitä tasa-arvolla ymmärretään globaalissa maailmassa. Kärjistäen voitaisiin väittää, että tasa-arvo mm. koulutuksessa, kuten kaikilla muillakin sektoreilla, on ylellisyyshyödyke, johon pystyvät vain erittäin hyvin menestyvät valtiot ja nekin uudelleen ajatellulta pohjalta.

Globaali kilpailu, josta olemme nähneet vasta pienet ensi aallot, suosii huippuosaamista. Jokaisella työyhteisöillä on oltava muutama keihään kärki, joilla se pystyy voittamaan tarjouskilpailut, koska vain voitot lasketaan! Hopeasija on yhtä huono kuin viimeinen. Siitä aiheutuu vain kustannuksia.

\section{Haasteet yliopistojen ja korkeakoulujen koulutukselle ja kehittämiselle}

Globaali maailmantalous vaikuttaa myös kasvatuksen ja opetuksen alueella suuremmin kuin ehkä osaamme arvatakaan. Tässä muutamia lähiajan arvauksia:

1 Koska lähes koko suuri ikäluokka eli noin 300000 ihmistä ohjattiin valtion tuella kunnallisiin työtehtäviin 70- ja 80-luvuilla, myös kaikenasteinen ja monimuotoinen kasvatus-, harrastus- ja sivistystoiminta koki kulta-aikansa. Vaikka tarpeet kasvavat 2000-luvulla, valtaosa nykyisestä toiminnasta ulkoistetaan ja eri intressiryhmät joutuvat ottamaan taloudellisen vastuun tekemisistään. Vähenevät ansiotyötä tekevät ihmiset ohjataan yhteiskunnan kannalta tärkeisiin, ulkomaista rahaa tuoviin tehtäviin. Muiden ihmisten rahoilla elävä ja työskentelevä valtaisa joukko joutuu poh- 
timaan tuottamansa lisäarvon uudelleen ja sitä myös evaluoidaan kriittisesti. Verkostoitunut toiminta vähentää virkamiestarvetta.

Yliopistot ja ammattikorkeakoulut joutuvat etsimään rahansa budjetin ulkopuolelta voidakseen suorittaa edes perusopetustehtävänsä, tutkimuksesta puhumattakaan. Koko sektori joutuu perustelemaan olemassaolonsa oikeutuksen. Rakenteellinen uudelleen organisointi osoittautuu välttämättömäksi seuraavan 10 vuoden aikana. Esimerkiksi joudutaan kysymään, että ovatko aloituspaikkojen suhteet, jotka syntyivät 1980-luvun suljetussa Suomessa, oikeat globaalissa maailmassa. Tässä tarkastelussa yhteiskunta-, käyttäytymis- ja humanistiset tiedekunnat joutuvat erityistarkkailuun. Tiedekunnathan kouluttavat nuoria pääasiassa valtion ja kunnan virkoihin, jotka eivät liiemmälti rahapulassaan rekrytoi. Oireet näkyvät jo nyt selvästi, kun yli 100 yliopistojen kasvatusja aikuiskasvatustieteen, psykologian ja sosiaalipsykologian ym., opiskelijaa ottaa TKK:n työpsykologian ja johtamisen professuurista 30-40 opintoviikon paketin tutkintoonsa päästäkseen yksityiselle sektorille töihin ja jopa onnistuvat siinä.

2 Yliopistojen professuurit ovat globaaliin maailmaan siirryttäessä liian pieniä ja liian yksitieteisiä. Voidakseen toimia kansainvälistyneessä kentässä, ydintyötä eli opetusta ja tutkimusta tekevien määrän pitäisi olla ainakin 15-30 henkeä. Jos henkilöstö koostuu, kuten työpsykologiassa diplomi-insinööreistä, psykologeista, aikuiskasvattajista ja ekonomeista, saadaan aikaan foorumi, jossa eri tiedepohjalta olevat ihmiset voivat yhdessä ratkoa riittävän isoja kehittämisongelmia muuttuvassa työelämässä, missä ongelmat ovat kietoutuneet toisiinsa.

3 Mainokset ammattikorkeakoulujen käytännönläheisestä opetuksesta pitäisi ottaa suurennuslasin alle. Mitä yksittäiset opettajat aineissaan tietävät yritysten ja työyhteisöjen ongelmista tehtyään työtään 10-20 vuotta luokkahuoneessa ilman tutkimus- tai kehittämiskokemusta? Ainakin työpsykologian kentällä tilanne on täysin päinvastainen. Yksikön tohtorit, lisensiaatit, psykologit, diplomi-insinöörit ja opiskelijat ovat viikoittain kentällä "haalarit päällä“ auttamassa työyhteisöjä ja

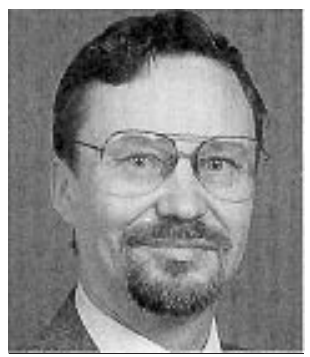

Veikko Teikari

sen lisäksi opettavat ammattikorkeakoulujen opettajille työskentelyä työyhteisöjen kehittämisessä.

4 Jos yliopistot haluavat laajentaa toimintaansa yhteistyössä kansainvälisten ja kansallisten yritysten kanssa, tietoa on opittava tuotteistamaan. Perinteinen teorioiden ja tutkimusmenetelmien kehittäminen sekä kirjojen tai artikkelien kirjoittaminen varmasti säilyvät tieteellisen toiminnan perusasioina, mutta ne eivät tulevaisuudessa riitä ainoiksi työkaluiksi, kuten Antti Paasiokin selvityksessään totesi. Oma profiili terästetään tietotuotteilla, joissa huippuosaaminen voidaan pakata esimerkiksi CD-rommille hypertekstimuotoon harjoitustehtävineen, kalvopohjineen ja toimenpidevirikkeineen sellaiseen muotoon, että yrityksen henkilöstö ja kehittäjät voivat nostaa toimintansa tasoa ilman, että asiantuntija on koko ajan auttamassa.

Viimeisen viiden vuoden aikana työpsykologian laboratorio on opetellut tätä vaikeaa tehtävää. Kansainväliset kokeilut eri puolilla Eurooppaa ja Kauko-Itää kotimaan lisäksi kertovat, että uudet mahdollisuudet kaupallistaa tieto ovat kiehtovia. Tällaisia tietotuotteita ovat simulaatiopeli (Piispanen ym. 1996), yhteistyöpeli (Ruohomäki 1996, Jaakola \& Ruohomäki 1997), Tiimivalmentaja plus (Koivula ym. 1998) ja vuorovaikutteinen tietotukijärjestelmä (Vartiainen ym. 1996, Kasvi ym. (1996).

\section{Miten yliopistoyksikkö oppii yhteistyön yritysten kanssa}

Kunhan suomalaiset valtion yritykset on yksityis- 
tetty ja ylimääräiset rahat tutkimukseen käytetty ja samanaikaisesti ajaudutaan kansainväliseen taantumaan, yliopistojen taloudellinen asema huononee nopeasti. Koska rakenteellisiin uudistuksiin ei todennäköisesti kyetä maanlaajuisesti eikä yliopistojen sisäisesti, jää ainoaksi vaihtoehdoksi juustohöylätä kuukauden tai kahden palkka pois henkilöstöltä vuosittain. Tässä tilanteessa pätevät nuoret tutkijat ja opettajat hakeutuvat töihin yksityissektorille ainakin teknillisellä ja kaupallisella aloilla.

Miten tällaisen todennäköisen, joskaan ei toivottavan uhkakuvan, voi välttää? Vastaus on yksinkertainen. Yliopistoyksiköiden on itse opeteltava tekemään rahaa, jolla korvataan budjettirahojen menetykset. Vaihtoehtoja on monia:

1 Kehittyä tutkimuksen huippuyksiköksi, jolloin on mahdollisuus työskennellä kansallisella ja kansainvälisellä tutkimusrahoituksella. Jos nyt ei ole huippuyksikkö, on kuitenkin vaikea saada yhteiskunnallista rahoitusta täyspäiväisten tutkijoiden palkkaamiseen ja siksi prosessi kestää kauan.

1 Ruveta myymään osaamistaan täydennyskoulutuskeskusten, avoimen yliopiston ja EU:n sosiaalirahastojen rahoittaman koulutuksen toteuttamisessa. Tällöin yksikkö joutuu todennäköisesti tinkimään melkoisesti tutkimusintresseistään.

1 Opetella yhteistyön tekemistä yritysten ja työyhteisöjen kanssa erilaisilla tutkimus-, kehittämis- ja konsultointisopimuksilla. Pisin historia tällä alueella on teknisillä ja kaupallisilla professuureilla. Tälläkin toiminta-alueella tie on pitkä ja kivinen. Pitää ensinnäkin kehittää osaamista, josta työyhteisöt ovat valmiita maksamaan, pitää opetella ymmärtämään yritysten toiminnan ja talouden ohjaamista, pitää rekrytoida markkinointi- ja yrittäjähenkisiä ihmisiä, jotka ovat esiintymiskykyisiä. Pitää pystyä maksamaan kilpailukykyistä palkkaa yrityksiin ja konsulttiyhtiöihin verrattuna pystyäkseen pitämään pätevän henkilöstönsä riittävän pitkään ja pitää opetella tapa tehdä sekä tiedettä että käytännön kehittämistoimintaa toisiaan tukien. Kuten Lawler (1985) ehdottaa, yliopistot ja tutkimuslaitokset joutuvat glo- baalissa maailmassa esittämään kaksi kysymystä arvioidessaan tutkimustaan ja projektejaan:

\section{Onko tästä hyötyä käytännölle?}

Kytkeytyykö se tieteellisen tiedon ydinrunkoon, joka on revelanttia teorian muodostukselle?

$\mathrm{J}$ okainen ymmärtää, että tällaisen työyhteisön luominen yliopiston sisälle ottaa aikaa. Työpsykologian laboratoriolta se otti noin 5-10 vuotta. Sen jälkeen viimeiset kahdeksan vuotta toiminta on vuosittain kasvanut. Henkilöstöä oli vuonna 1998 oli 55, joista 45 saa palkkansa maksullisen palvelutoiminnan kautta. Työpsykologian kokonaisbudjetista omarahoitteisen toiminnan osuus oli 69 prosenttia Yksikkö on siis nykyään melko riippumaton valtion budjettirahoituksesta. Sitä kylläkin auttaa opetuksen huippu- ja laatuyksikön status vuosina 97-98 ja 99-00 pienine lisärahoineen.

Jos tällaiseen toimintaan lähtee, tarvitsee olla valmis muuttamaan johtamisperiaatteitaan. Perinteinen professorivalta purettiin työpsykologiassa vuonna 1992 kaksivuotisten keskustelujen tuloksena ja ruvettiin luottamaan tutkijoihin. Valta ja erityisesti rahavalta delegoitiin yksilöille, työpareille ja yhä lukuisimmille tiimeille. Samalla tämä tarkoittaa yrittäjämäistä toimintaa työpsykologian sateenvarjon alla. Jokainen tutkijaryhmä johtaa itsenäisesti toimintaansa eli hankkii projektinsa ja neuvottelee sopimuksensa, organisoi työskentelynsä, kirjoittaa raporttinsa, määrittelee työsopimuksensa ja palkkansa keskenään, hoitaa itsenäisesti omat kansainväliset ja kansalliset tutkijaverkostonsa sekä rekrytoi omat jäsenensä.

Nykytilanteessa työsuhdeturva on voitetun tarjouksen mittainen ja palkkajouston haarukka on hyvin iso ylös- ja alaspäin tilanteen mukaan. Maksuliikenne hoidetaan valtion ohjesääntöjen mukaan TKK:n kautta. Siksi jokainen projekti maksaa TKK:lle normaalit yleiskulunsa ja vuodesta 1999 alkaen 10 prosenttia hallintomaksun entisen kuuden prosentin sijaan. Lisäksi jokainen projekti antaa rahoistaan noin 10 prosenttia Työpsykologian laboratorion infrastruktuurin ylläpitämiseen (esi- 
merkiksi ostamalla tietokoneensa, kännykkänsä ja hoitamalla niistä aiheutuvat puhelinkulut, maksamalla konferenssimatkansa ja osallistumalla mahdollisiin suuriin yhteishankintoihin jne.). Lisäksi lähes jokainen projektiryhmä tuottaa ainakin yhden kurssin, ja tästä syystä yksikön opetustarjonta on lisääntynyt muutamassa vuodessa kolminkertaiseksi. Jokainen yhteisön jäsen tekee lisäksi tieteellistä työtä, lehtiartikkelien, kirjojen, konferenssien yms. kautta. Jokaisella on myös velvollisuus jatko-opintojen harjoittamiseen. Toiminta on tälläkin saralla pitkällä viiveellä tehostunut, josta kertoo neljä väitöskirjaa syksyllä 1998. Aktiviteetti näyttäisi jatkuvan tällä tasolla muutaman seuraavan vuoden ajan.

$\mathrm{K}$ un tutkijatiimi työskentelee riittävän kauan (2-3 vuotta) yhdessä, se pystyy tukemaan toimintaansa keskinäisellä avunannolla ja autta-

\section{LÄHTEET}

JAAKOLA, M. \& Ruohomäki, V. (1997) Yhteistyö sujuvaksi pelaamalla. Teollisuustoimihenkilöiden jäsenlehti, (12), 7.

KOIVUlA, A., Aaltonen, P., Pankakoski, M., Ventä, M.
\& Nieminen, M. (1998) Tiimivalmentaja plus. CDrom. Espoo: TKK, Työpsykologian ja johtamisen laboratorio.

LAWLER, E. (1985) Doing research that is useful for theory and practice. San Francisco:.CA Jossey-Bass.

KASVI, J.J., Nieminen, M., Pulkkis, A. \& Vartiainen, M. (1996) Teollisuustyön vuorovaikutteinen tietotukijärjestelmä. Teoksessa J. Kasvi \& T. Argillander (toim.).Tietotekniikka osaamisen tukena. HUT Industrial Management and Work and Organizational Psychology, Working paper No 4, Otaniemi, 35-52.

PIISPANEN, E., Pankakoski, M., Ruohomäki, V. \& Teikari, V. (1996) Simulaatiopeli hallintotyön kehittämiseksi. Käsikirja. Hallinnon kehittämiskeskus \& Teknillinen korkeakoulu, Työpsykologian laboratorio. Hakapaino: Helsinki.

Piispanen, E., Ruohomäki, V., Pankakoski, M. \& Teikari, V. (1996 The work flow game - a new method for developing office work. Teoksessa: D. Saunders, F. Percival \& M. Vartiainen (toim.).Simulation and gaming yearbook. Games and simulations to enhance learning. London: Kogan Page, 4, 85-95.

RUOHOMÄKI, V. (1996 Towards fluent teamwork. Teoksessa: P. Odenrick \& M. Pankakoski (toim.). Simulation and game methods for change at work. The first Lund - Otaniemi workshop. Change and work, Report: 1, 19-21.

VARTIAINEN, M., Pulkkis, A., Kasvi, J.J. \& Nieminen, M. (1996) The critical job and organisational demands for the design of information support systems. Teoksessa:.W. Hacker, P. Richter \& T. Wagner (toim.). Analysis and design on mental work. Dresden:.Dresden University of technology, 19-36. 